\title{
Analytical Measuring and Visualization of Spatio-Temporal Change in Built Environments: Beyazıt Square Case Study Area in Istanbul
}

\section{Yapılı Çevrelerde Zamana Bağlı Mekansal Değişimin Analitik Olarak Ölçülmesi ve Görselleştirilmesi: İstanbul Beyazıt Meydanı Örnek Alan Incelemesi}

\author{
Harun Ekinoğlu, Ayşe Sema Kubat \\ Department of Urban and Regional Planning, Istanbul Technical University, Istanbul, Turkey
}

\begin{abstract}
Tobler's First Law of Geography states that nearby things are more related than distant things. In other words, there is a close relationship between nearby things compared to distant things. This also implies that built form is in a relational process in its topologic embodiment and the overall spatial form emerges a certain degree of wholeness. Mediating C. Alexander's "levels of scale" property as a morphologic translation interface and using Shannon's Entropy theory as a data-mining method, this study allows revealing the degree of uncertainty and disorderliness that a certain spatial complexity embodies. Shannon's Entropy, a method of measuring the information, has been employed in this study in measuring the state of uncertainty and disorderliness conveyed through the multi-scalar context of built configuration across scales. Results have been hypothesized to correlate with the degree of wholeness, in other word completeness, of the case built area. Beyazit Square with its 50-hectare environs in the Peninsula of Istanbul has been selected as the case area due to the remarkable change that the square experienced through a harsh urbanization over the last sixty years. Building footprints belonging to two time periods have been used as raw data. Multi-scalar analyses conducted upon the data of 1946 and 2013 revealed that the wholeness of the square has deteriorated, from 0,77 bit to 1,02 bit entropy level within last sixty years. This finding is being verified by the remarks of the spatial assessments done for the square and visualized by the color-coding way of data-visualization.
\end{abstract}

Keywords: Wholeness; morphology; entropy; change; relationality.

\section{ÖZ}

Tobler'in "Birinci Coğrafya Kanunu” birbirine yakın mekansal unsurların, uzak unsurlara göre birbirleriyle daha ilişkili olduğunu belirtir. Diğer bir deyişle, birbirine yakın bileşenler veya parçalar arasında birbirine uzak bileşenlere veya parçalara kıyasla daha yakın bir ilişki vardır. Bu aynı zamanda yapılı çevrenin ilişkisel bir süreç içinde topolojik olarak vücud bulduğunu ve toplam mekansal oluşumun belli bir bütünlük derecesi ortaya çıkardığını ifade eder.

Bu araştırma, C. Alexander'ın “Ölçek Dereceleri” bütünlük özelliğini C. Shannon'ın “Shannon Bilgi Enropisi” ile birlikte morfolojik bir çeviri arayüzü olarak kullanarak veri elde etmekte ve bu yolla mekansal bir formun barındırdığı belirsizliği ve düzensizliği ölçmeye izin vermektedir. Verilen bir bilgiyi ölçme yöntemi olarak Shannon'ın bilgi entropisi teorisi bu araştırmada yapılı çevrelerin çok ölçekli bağlamlarının taşıdığı belirsizlik ve düzensizliklerinin ölçülmesinde kullanılmaktadır. Sonuçlar incelenen örnek yapılı çevrenin bütünlük derecesini açıklamada kullanılmaktadır. Son 60 yılda geçirdiği yıkıcı kentleşme, yaklaşık 50 hektarlık yakın çevresiyle birlikte Beyazıt Meydanı'nda dikkate değer bir değişime yol açtı. Bu değişimi, geliştirilen yöntem ile ölçmek amacıyla, ham veri olarak 1946 ve 2013 yıllarına ait bina ayak izleri vektörel verisi kullanıldı ve çok-ölçekli analizler sonucunda elde edilen sonuçlar meydanın son 60 yılda toplam bütünlüğünün, toplam entropy-iqr değerinin 0,77 'den I,02'e çıkarak, önemli oranda azaldığını ortaya koymaktadır. Örnek alan analizleri sonuçları meydanda yapılan değerlendirmelere ait raporların tespitlerini desteklemekte ve bu tespitler tarafından doğrulanmaktadır. Alanda yapılan değerlendirmeler ayrıca renk-kodlaması görselleştirmesi sonuçlarıyla da tutarlılık arz etmektedir.

Anahtar sözcükler: Bütüncüllük; değişim; entropi; ilişkisellik; morfoloji. 


\section{Introduction}

It is due to our cultural context, maybe even due to our natural state of being alive, that we admit more value to life than a machine. We are biased. The distinction between machine and life boils down to the question of reproducibility. Only because we humans can dis- and reassemble a car makes it a machine? Is it too simple to be a system that has more value than the sum of its parts? The reason why a living organism is dead when disassembled and does not come to life anymore when reassembled is that first; we're not able to disassemble without destroying it and second; living organisms, like ourselves, can be seen as an ongoing self-maintaining process. Once stopped, it would need to restart from the very first cell division to become alive again. That's how we actually reproduce ourselves. Mehaffy and Salingaros (20I I) state that there is no way to decompose an organism into its parts without destroying the connective networks -subsystems- that make the whole system work.

There are pros and cons of applying the notion of a "living" and therefore biological organism to a city. One concern to point out here: Similar to biological organisms can't we reassemble a city? Practically, we can! The "city life" wouldn't be exactly the same as before, but there would be a life. Even in a city that has not been destroyed and reassembled, public life changes every day. Therefore, there is a loose relationship between wholeness and life. The notion of wholeness is too closely tied to the concept of life. It has been asked at what point a human being mentally and physically conceives itself as a whole. There are so many ways of being incomplete as a person and still being alive, that the entire question of wholeness is a large, flexible and not so clear phenomenon. In the middle ages a city without basic elements such as a wall protecting it was not a city. Then the entire definition of spatial wholeness and so the notion of "living structure" appears to be a matter of time, space and cultural relevancy.

The place is an adaptive cultural process. It may be incomplete or imperfect and yet can have a life. Adapted to spatial analysis, the question might be phrased as: how whole or how complete is a space or an area based on the information conveyed through its various, multi-scalar, morphologic possibilities? Shannon's entropy (1948), (200I) as a measure of uncertainty for conveyed morphologic information, is a consistent way to apply as the core data mining method in this study.

Alexander's (2002-2005) overall idea of wholeness and life stands on a strong assumption of completeness. The wholeness of a built system is not about the quality and behavior of every single entity what Alexander (2002-2005) calls "center", but about the way they come together and therefore make each other strong across scales. This implies an emer- ging and holistic sense of completeness about the relative size, shape, and density of centers in making a greater whole. This was one of Alexander's major questions to himself in seeking of any structural features that tend to be present in those systems with more life (Alexander, 2002-2005, p. 144). He thinks that everything that has wholeness has also life and vice versa. Yet, the question arises around the need for a quantifiable definition of wholeness. It is obvious that Alexander's (2002-2005) definition of wholeness as a phenomenon is highly related to the concept of order. Yet, this is not a shallow understanding of order that only exists in nature but a quality that may exist in everything.

At the end of intensive studies on the phenomenon of wholeness, Alexander (2002-2005, Pp. 244-289) distilled fifteen structural features that he thinks are the ways every possible sub-component in a system, he calls centres, come together and make each other strong so that the whole system generates a certain degree of wholeness and life. Alexander's fifteen properties of wholeness are (I) levels of scale, (2) strong centres, (3) boundaries, (4) alternating repetition, (5) positive space, (6) good shape, (7) local symmetries, (8) deep interlock and ambiguity, (9) contrasts, (10) gradients, (II) roughness, (I2) echoes, (I3) the void, (I4) simplicity and inner calm, and finally (I5) non-separateness. Properties are the elaborative explanations of observations that were recorded in "Timeless Way of Building" (Alexander, 1979, p. 242). A "property", as a relative quality, in Alexander's texts, is a fundamental informative characteristic for wholeness and life (Waguespack, 2010). Alexander in this respect states that $90 \%$ of our human feelings are shared, and idiosyncratic parts which vary from people to people only account for 10\% (Alexander, 2002-2005) and claims that human feeling is a legitimate instrument for recognizing the wholeness. However, it is still intuitive and pseudo-scientific which yet needs scientific confirmation (Marshall, 20I2).

In order to understand "levels of scale" property in a comprehensive way, one may observe how an electric discharge in an electric field motion occurs and vanishes in a rush to recreate itself as in Figure I. There is a recursive behavior that repeats and brings itself into a new order through strongest to weakest zones in an everlasting way. Levels of electric zones create gradients and echoes through alternating repetitions as the integral parts of a robust whole. Alexander notes that it is not hard to see that in any system where there is a good functional order, there is also a good spatial coherence with a legible hierarchy (Alexander, 2002-2005, s. 246). In such hierarchy, the interplay among one level or size tends to be in a topo-geometric relationship with the nearest structural context. Tobler (1970) in "First Law of Geography" states that nearby things are more related than distant things. In other words, there is a close relationship between nearby things 


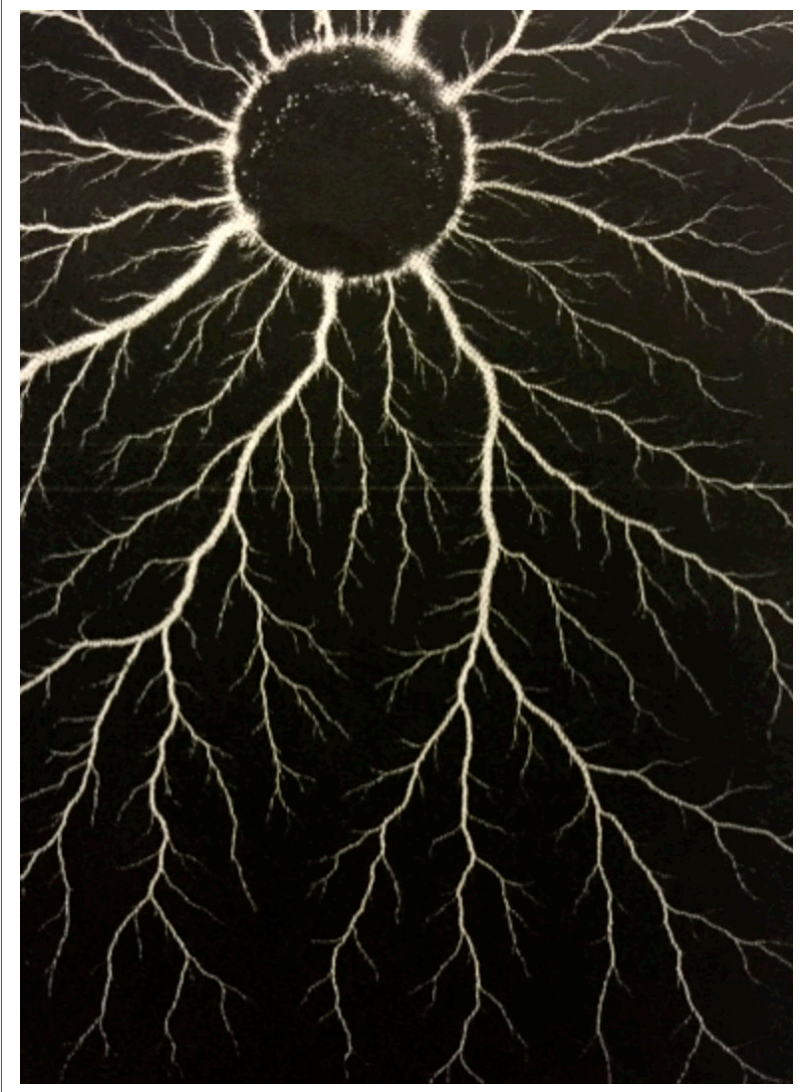

Figure I. Electric Discharge in an Electric Field (Alexander, 2002-2005, p. 247)

compared to distant things. This also implies that built form is in a relational process in its topologic embodiment and the overall spatial form emerges a certain degree of wholeness.

A structural complexity can be more or less alive depending on the degree of wholeness it has (Alexander, 2002-2005). Early major attempts to measure the wholeness of things or systems analytically were "Gestalt Psychology" (Köhler, 1947) and "Quantum Physics" (Bohm, 1980) in which wholeness mathematically is defined as a recursive physical structure. Alexander (2002-2005) in this respect noted that there was no mathematical approach at that time to unearth the meaning of wholeness embedded in things and reflectively in the human psyche (Jiang, 2017). In brief, Alexander described wholeness as a phenomenon in profound details and widest perspective that no other approach has done before.

In brief, the method does not only offer a new possibility in measuring the spatial order in cities but also testing major Urban Design theories that stand on "non-validates claims" in Marshall's definition (2012). Some of the most well-known ones are raised by Kevin Lynch (1960), Jane Jacobs (196I), Gordon Cullen (196I), and C. Alexander (1963), (1965), (1987), (2002-2005) who place most of their theories for ro- bust urban spaces on relative spatial configurations in two and three-dimensional space settings. The method also gives an opportunity to articulate if the notion of wholeness is purely intuitive as Alexander (2002-2005) suggests, or an evidence-informed notion that can be better measured in a computational way.

In various organic systems in nature, the structure of the whole organism is often reflected in every part of various scale levels because of the proposal that corresponding forces act on each part in a hierarchical scaling structure. The forces that shape the branch shape the sub-branch that shapes the twig (Harris, 20I2).

Mandelbrot (1977), for the first time, in his influential work "Fractals" claimed that there is an order in the physical roughness, irregularity, and chaotic systems of the universe. His approach changed our view of the mathematical and physical universe and paved the way for several disciplines, from finance to computer science, to reconsider scale, system, and probability issues. In this sense, the method defines a capacity to make a computational assessment of the multi-scalar complexity and mathematically unearths the hidden fractal nature of the built environment using a data-translation method.

C. Alexander's (2002-2005, pp239-24I) several of the fifteen properties of wholeness, Levels of Scale, Alternating Repetition, Deep Interlock and Ambiguity, Gradients, Echoes, and Not-Separateness describe certain ways of systematic clustering of the system sub-constituents. They all describe different ways that centers may come together and interact. The proposed method, for the analysis built environments, draws a potential to dismantling the morphologic formation to the smallest or largest possible constituents to examine the relational behavior of space with various relevant issues that can be associated with space.

\section{Dataset and Method}

Alexander's assertions require scientific confirmation and this study raises the question of whether or not we can analytically measure Alexander's definition of wholeness or completeness using "Shannon's Entropy" (Shannon, 1948). In other words, this study develops a mathematical model of wholeness through generating the entropy for particular pixel levels out of building footprints raw data. Scale level in the proposed method refers to the varying pixel categories in data-mining. Scale in this kind of information retrieval process acts as a dynamic grid interface with equally divisible units upon any area's raw data. Size of the grid units is dependent on the number of pixels that are framed for each scale level as seen in Figure 2 below. In other words, for each scale level, the area is overlaid by a different grid in which each equiva- 


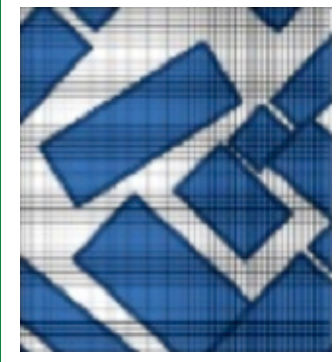

100

$15 p x^{*} \mid 5 p x$

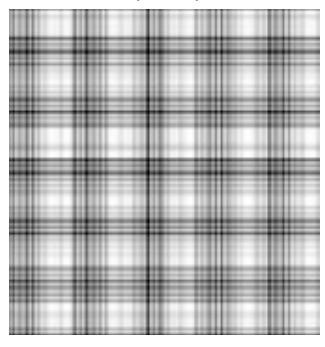

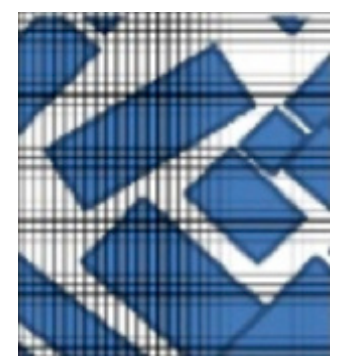

200

$30 p x * 30 p x$

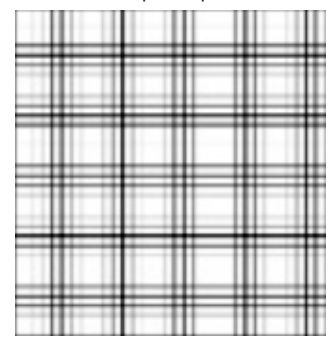

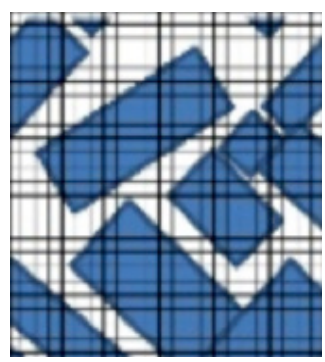

300 $45 p x^{* 45 p x}$

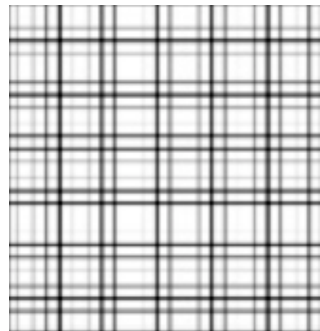

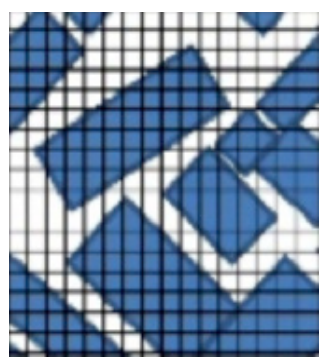

400 $60 p x * 60 p x$

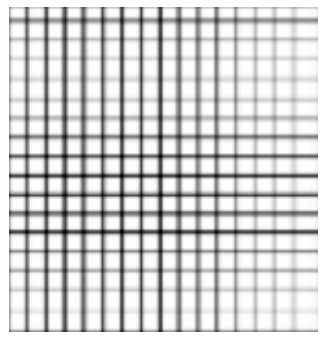

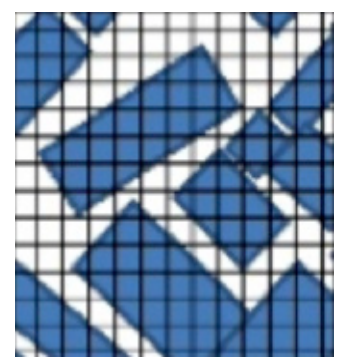

500 $75 p \times * 75 p x$

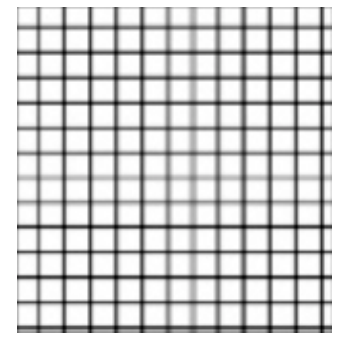

Figure 2. Scaling the grid and thus the number of the pixels framed by each grid unit

lent unit frames a different pixel density and thus a different morphologic formation. Eventually, in each scale level, through varying morphologic formations framed by each unit, varying entropy values are calculated throughout the grid as in Figure 2 below.

This study, using Shannon's information entropy theory, develops an alternative quantifiable approach that can measure the contextual nature of completeness for a built environment from the scale levels point of view. In order to achieve it, a spatial analysis tool has been developed by using two major programming languages; "C\#” developed by Microsoft (20I5) and "Processing" developed by Ben Fry and Casey Reas (Jones, 2010). The tool has two major functions: I) Data-mining and 2) Data-visualization. The data-mining function has been developed by compiling diverse image processing algorithms on $\mathrm{C \#}$ to retrieve data via a hybrid feature extraction algorithm out of building footprints' raster data which exposes only the buildings as the three-dimensionally constructed elements upon the ground. Data-visualization function visualizes the retrieved data sets and illustrates the outcomes of the analysis. For this case analysis, building footprints vector data, for 50 hectares (500.000 m2) urban areas with $1024 \times 1024$ pixels resolution, has been selected as raw data. For two different configurations belonging to two different time periods, - 1946 and 2013-, as seen in Figure 6, two different mean Entropy-IQR values have been generated via 10 different grid scales.

Statistical entropy was first introduced by Shannon (1948), (200I) as a basic concept in information theory, measuring the average missing information on a random source (Jat et al. 2007). Shannon's entropy originated from information theory as a measure of uncertainty of conveyed information over a noisy channel (Bailey, 2015), (Jat et al. 2007). The larger the value of Shannon's entropy, the higher is the uncertainty of information conveyed. Shannon focused on how to minimize the loss of information in revealing a message in another point. Entropy $(H)$, in this sense, is a measure of information. $H$ is dependent on the number of information categories, K. Higher the amount of data categories conveyed by an information, less probability of the same type of category to gather. It is also the least predictable state (Bailey, 20I5), (Waguespack, 20I0). Therefore, the entropy is always towards most probable or most likely state. By the same logic, the higher the spatial entropy, the more the uncertainty is, hence a larger potential towards change. Bailey (2015) states that Shannon's entropy is content-free and can be applied to measure any type of data with a multiplicity of information.

Shannon entropy is a quantity measuring the relations in a data category. Use of logarithm makes this quantity growing linearly with system size and "behaving like information". Shannon in his original paper states that the logarithmic measure is more convenient since it is mathematically suitable for measuring the number of possible states in which a system can be found. The unit of entropy is a "bit" (Wang, 2016). As it is distilled from diverse definitions of wholeness and Alexander's assertions (Alexander, 2002-2005, s. 64, 72, 77, 78, II2, I22, 144, I45, 146) it is possible to say that low entropy implies a relatively higher degree of wholeness (Shannon, 1948), (Leibovici, 2009).

Starting from Alexander's views on wholeness, the ultimate purpose of this study is to develop a mathematical model to unearth the degree of spatial uncertainty of a particular built 
area in relation to its immediate context. Using entropy in this sense helps to measure the complex and multivariate information of two-dimensional morphologic layouts conveyed through the units of a grid system superimposed upon the analyzed area. Entropy $(\mathrm{H})$ by definition is a configuration-dependent concept. It is the measure of uncertainty that each unit holds considering of eight adjacent units' total built probability $(\mathrm{P})$ as illustrated in below Figure 3. G is the built probability specific to each unit area, while the entropy is generated for the units that are adjacent to eight units, as illustrated in Figure 3 below. In brief, $\mathrm{H}$ is a measure emerged through the relative morphologic state of adjacent unit areas.

Recent studies (Karlström \& Ceccato, 2002), (Li \& Reynolds, 1993), (Li \& Huang, 2002), (Maitre, Bloch, \& Sigelle, 1994), (Tupin, Sigelle, \& Maitre, 2000), (Claramunt, 2005) about use of information entropy in measuring the multivariate distribution of spatial co-occurrences is progressive (Leibovici, 2009). When reviewing the previous research in this field, the core struggle that emerges is about generating the entropy for the same context yet with different spatial configurations. Leibovici (2009), in this respect, notes that there is still a need for a coherent methodological approach that will consider the relatedness of constituting elements as an adjacency factor among

$$
\begin{aligned}
G_{i} & =\frac{\text { Built portion of pixel } i}{\text { Total built pixel area }} \\
P_{i} & =G_{i} / \sum_{i}^{l} G_{i} \\
H_{i} & =\Sigma P_{i} \cdot \log \left(\frac{1}{P_{i}}\right)
\end{aligned}
$$

Equations I, 2 and 3: G, P and H calculations using shannon's entropy

the analyzed data category.

Advancing the aforementioned progress on measuring the entropy of spatial complexities, this study develops a progressive approach. Referring to Leibovici's (2009) suggestion, the method is built on the ability to consider the nearness and relatedness as adjacency factors among the analyzed units of various grid scales. As seen in Figure 2 above, the tool developed for this research enables running the analyses for various scale levels. For the case study in this paper, the analyses have been conducted for the grid scales from I/I00 to I/I000 with regular intervals of 100 . Ten grid scale levels have been used in reference to Mandelbrot's fractal reading of observable universe that he introduced in his seminal work "Fractal Geometry of Nature" (Mandelbrot, 1982). Besides, the selected ten sca-
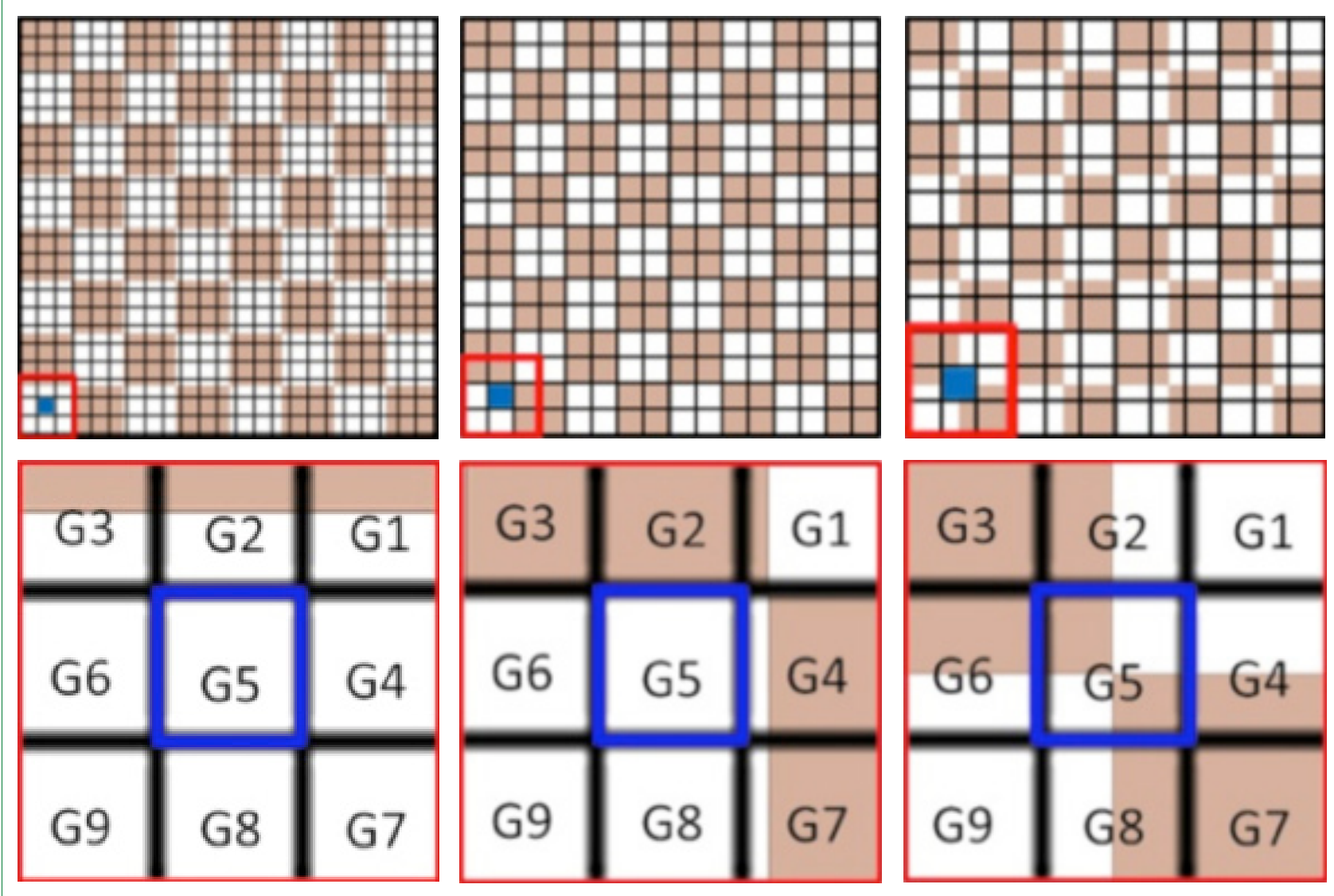

Figure 3. Unit positions and their interactions with adjacent units in calculation of $G, P$ and $H$ values 


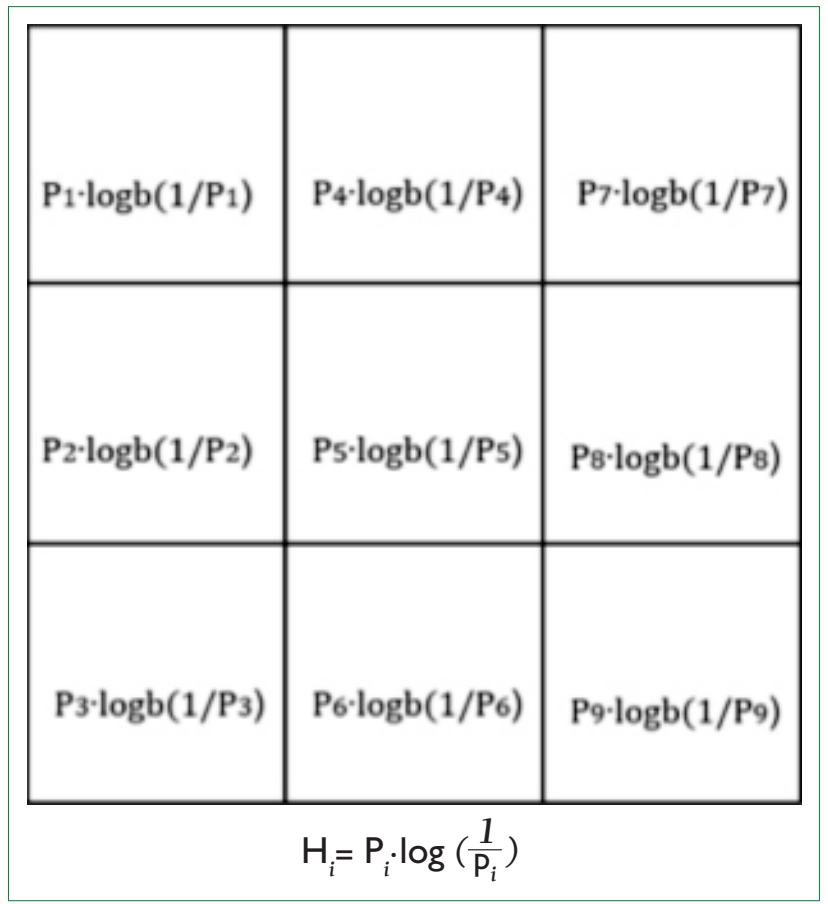

Figure 4. $P$ values of a 9-units system where each unit is the central unit of another 9-units system throughout the grid.

le levels are the ones that human-eye, through a 2D layout, can capture the relationalities of structural embodiments in a more coherent way. The way every single unit interacts with its eight adjacent units mathematically accounts in the calculation of entropy for each unit area except those by the grid edges. This leads to creating a highly varied data with varying spreads or deviations. In order to measure it, the multivariate nature of such data requires a discretization to eliminate the divergences.

Referring to Shannon's entropy as formulated in below equations (I), (2), and (3), Given $i$ is a central unit adjacent to 8 equivalent units, $n$ is the 9 adjacent units that form square sub-regions throughout the grid system. $G_{i}$, for the $i^{\text {th }}$ unit of the $n$ units of a sub-region in a grid system, is the unit-specific built portion. $\mathrm{P}_{\mathrm{i}}$ is the built portion of the unit $i$ divided by the total built portion of the nine units sub-region where $i$ is the central unit. For instance, as in Figure 3, the entropy $(H)$ for the 9-units sub-area where $\mathrm{G} 5$ is the central unit. $\mathrm{Pi}$ is that G5 is divided by GI, G2, G3, G4, G5, G6, G7, G8 and G9 values. $\mathrm{Pi}$ multiplied by $\log b\left(\mathrm{I} / \mathrm{P}_{\mathrm{j}}\right)$ where the base $(\mathrm{b})$ for the logarithm is $2 . H_{i}$ is calculated by taking the sum of each of the nine $P_{i}$ values in the 9-units system. In other words, the units by the grid edges are exempted in entropy calculation since they do not meet this criterion.

Each grid unit in Figure 3, matches a particular space and thus a particular portion of a morphologic occurrence represented by a $G$ value. If a unit partially frames a building or a group of buildings, the algorithm as in below equation I, assigns a ratio for the area of the built part divided by the total unit area depending on the scale of the grid. It assigns $G=0$ when the unit area is totally no-building, and $G=I$ when it fully frames a building or group of buildings.

The analysis allows generating a multivariate data with various deviations. IQR (Interquartile Range) is a statistical data measuring method that does a discretization for the data with varying spreads. It arranges the values from the smallest to the biggest. For discretization of the deviations along the data, IQR plays a role to extract the "middle fifty" where it draws a specified data as graphed using the Box and Whisker Plot in Figure 5 below. The extremes of the data are eliminated and it is where the bulk, middle fifty, of the data falls into. It is preferred over many other measures of spread in statistics when reporting about multivariate data sets. Due to fact that each output is scale-dependent, the ranges of the quartiles change as the scale of the analysis changes. In other

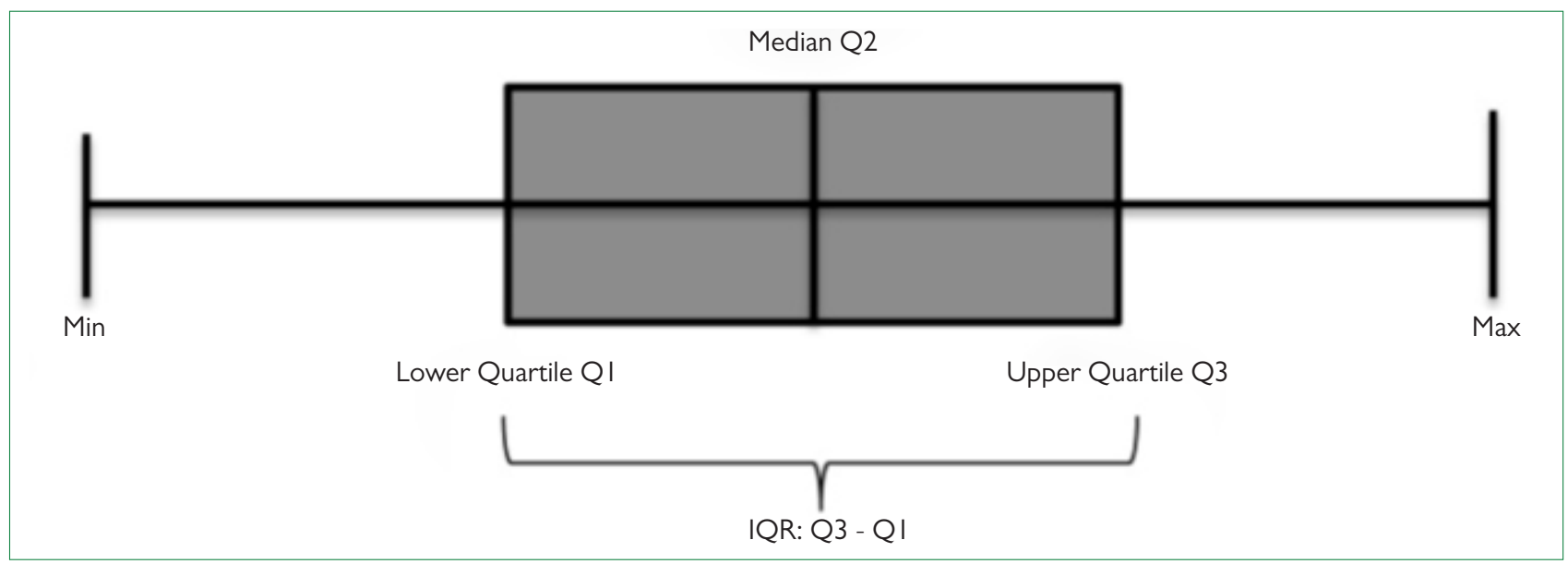

Figure 5. Generating the IQR Value through Box and Whisker Plot 
words, each IQR for a specific scale relies on the changing morphologic states that are framed by different size of grid units. By the IQR method, each output data is reduced to a single value. Multiple analyses for varying scales allow generating multiple IQRs. The mean of the Entropy-IQRs gives the final outcome of the analysis.

In the interpretation of IQR, knowing the values of quartiles, QI and Q3, has critical importance. The position of the quartiles, between 0,00 and I, 00, can be highly distinct, somehow close to each other or juxtaposed which at the end explains how the IQR is created in fact. When the quartiles are located distinctly far from each other, IQR gets a higher value. This also points to the deviations that exist along the entropy dataset. The deviations in the dataset point to the remarkable differences among the morphologic formations framed by the grid units, in other words among the $G$ values, unit based built probability, of the grid units. The differences gradually affect the aforementioned $P$ value in equation 2 above, the relational probability of 9 connected units as seen in Figure 3, and thus the entropy $(\mathrm{H})$ value in equation 3 .

In brief, the positions of lower and upper quartiles give information about the general morphologic character of the analyzed area. Approximate QI and Q3 values explain that there is a recursive, proportionally continuous, built pattern in the analyzed area. Analyses that are performed via grids with varying scale levels, do not necessarily affect the $G$ values and thus the $P$ and $H$ values significantly in a continuously built context since the quartiles keep staying recursively approximate or juxtaposed. This kind of scrutiny, using the proposed method, helps to understand that any certain continuous and legible spatial order, no matter how configured, most possibly generates approximate or juxtaposed quartiles and thus a lo-
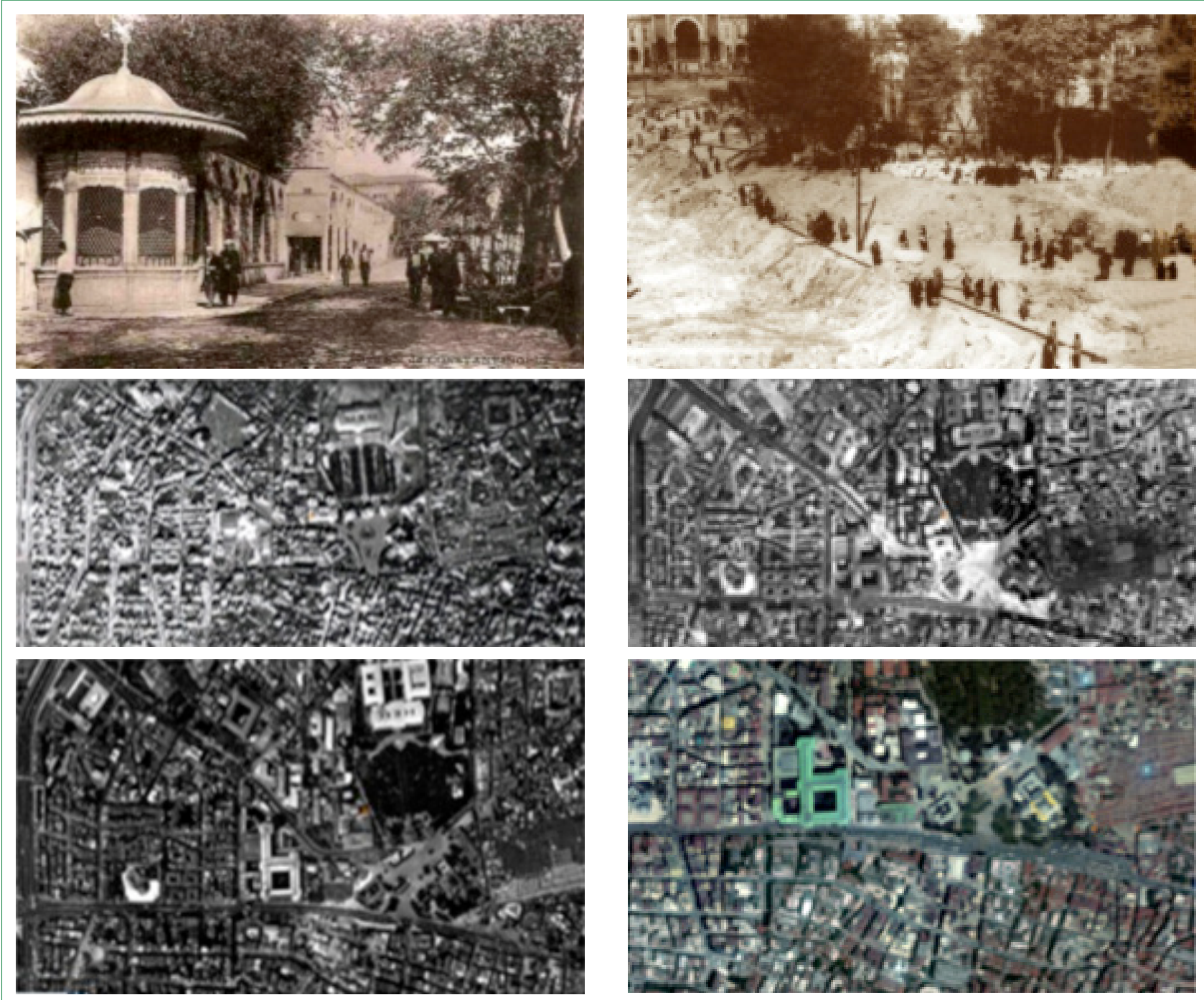

Figure 6. Enlarged Vezneciler (Upper-Left) and Ordu (Upper-Right) Street Views. Beyazit Square Aerial Views in 1946(Middle-Left), 1966(Middle-Right), 1982(Lower-Left) and 2013(Lower-Right) (IMM, 20I2) 
wer $\mathrm{H}-\mathrm{IQR}$ value as an indicator of higher wholeness.

Correlation in specific terms between the degree of wholeness embedded in the spatial layout and the feeling of wholeness revealed deep inside human being requires another research since the sense of wholeness is about complex agglomeration of manifold constituents that address intuitions. Without a doubt, Alexander never ignored functional, socio-cultural and architectural content in describing spatial wholeness yet it reminds the question of whether or not his I5 properties always grant a certain level of wholeness in real space.

\section{Case Study: Beyazit Square and its Evolution}

Beyazit Square was, and is, one of the most historic and symbolic squares of Istanbul Peninsula, throughout the history. The square exists on the third hill of the Historic Peninsula (Freely, 201 I, p. 183). The historical significance of the square dates back to the Roman period and known as Forum Tauri and Forum Theodosius in Byzantium period (Ayvazoglu, 2012) (Müller-Wiener, 2002). The square exists at the intersection of significant urban elements that make historic Istanbul image.

Beyazit Square experienced a serious demolishing interventions from the mid-20th century onwards urbanization resulting in a vast destruction of the existing built city form. Scholars (Müller-Wiener, 2002), (Eyice \& Kuban, 1993), (Ayvazoglu, 2012) note that the most destructive intervention upon the square occurred in 1950's through the implemen- tation of the Prost plan, which gave priority to the motorvehicle traffic. The enlargement and downing of the Ordu Street in the southbound of the square resulted in not only a massive fragmentation between the street and the square but also a remarkable change in the adjacent built environment of the square. In addition the Northwest access to the square, Vezneciler Street was also enlarged through a vast amount of massive destruction as shown in below Figure 6. Today one can still recognize the remaining parts and the fragments of the historic buildings on the site as seen in below Figure 6 street views (IMM, 20I2). Today, the architectural elements that make the square's identity are foremost the Istanbul University's main gate, the Beyazid Mosque Complex, the State Library of Beyazid and the Madrasa (Ayvazoglu, 20I2). Spatial assessment reports that have been developed by the Metropolitan Municipality of Istanbul (IMM, 20I2) and by the Protection Board for Cultural Assets (2013) point out to the poor spatial organization of the square due to remarkable change that the square faced within the last decades.

\section{Results}

Beyazit Square and its environs as shown in Figure 7, a 50 hectares $=500.000 \mathrm{~m} 2$ built area, has been selected for the comparative analysis due to the remarkable change that the square faced through the harsh urbanization over the last sixty years. Building footprints vector data ( $1024 \times 1024$ pixels .tiff files) belonging to two different time periods, 1946 and 2013, have been used as raw data for information retrieval. Both datasets have been analyzed through ten levels grid sca-

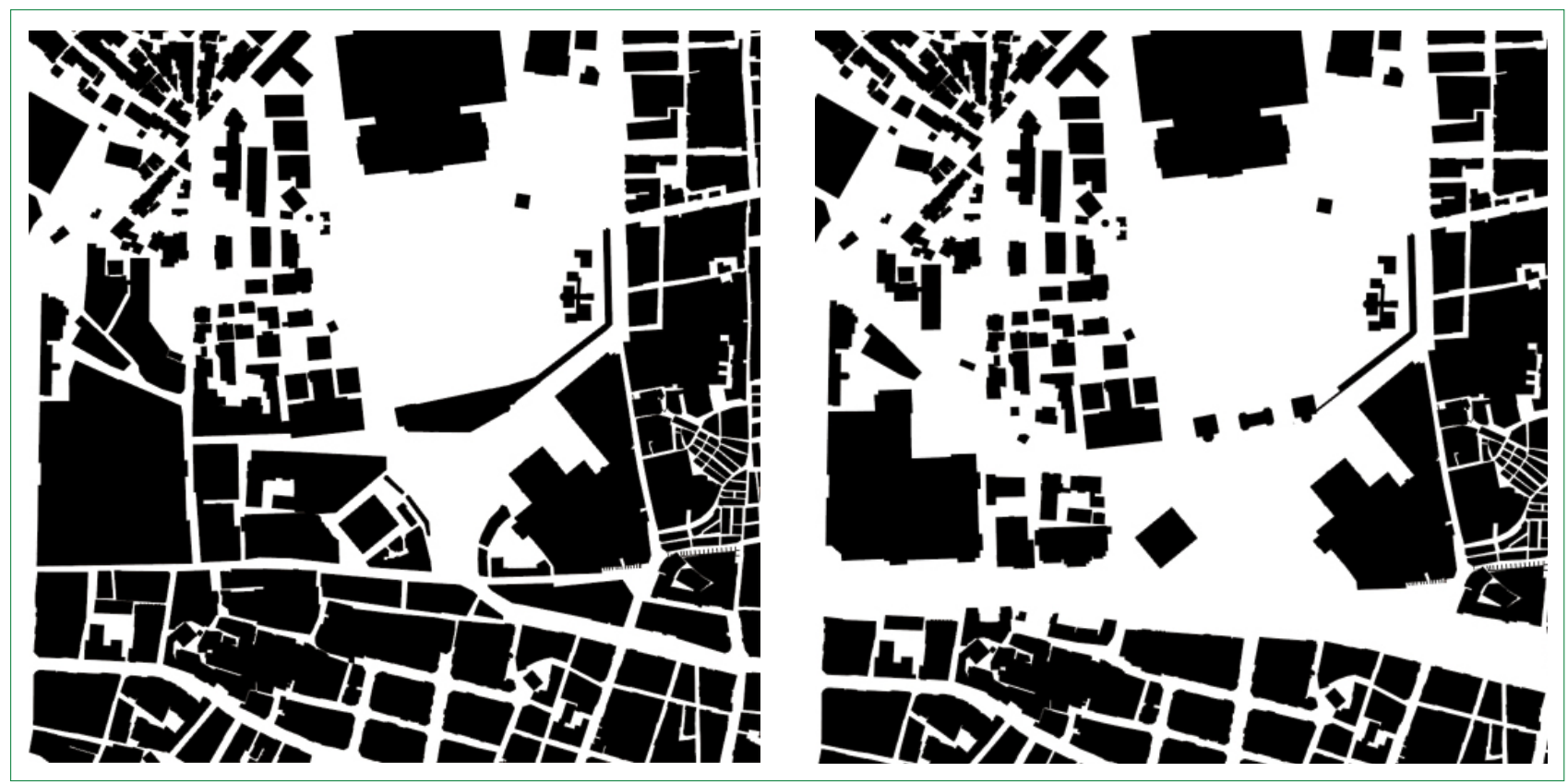

Figure 7. 50 hectares (500.000 sqm) Beyazit Square and Environs in 1946(Left) and in 20 I3(Right). (I024x 1024 pixels each vector data) 


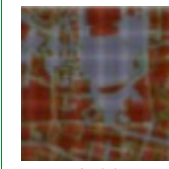

$1 / 100$

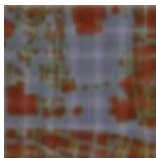

$1 / 100$

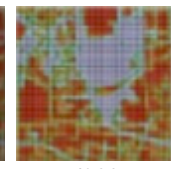

$1 / 200$

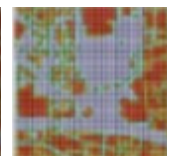

$1 / 200$

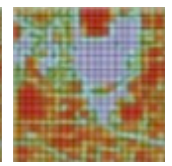

$1 / 300$

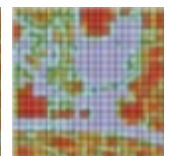

I/300

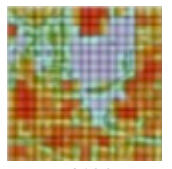

I /400

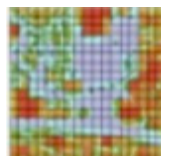

$1 / 400$

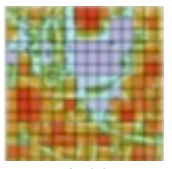

I/500

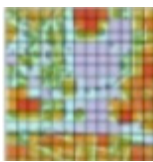

I/500

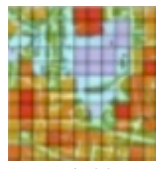

$1 / 600$

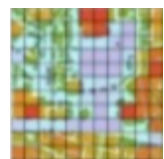

$1 / 600$

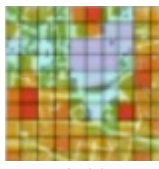

I/700

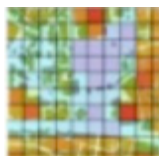

I/700

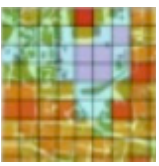

I/800

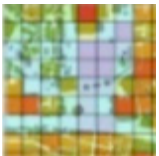

I/800

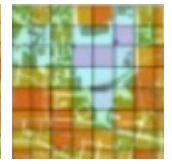

I/900

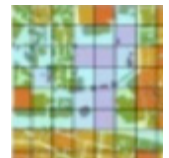

I/900
$1 / 1000$
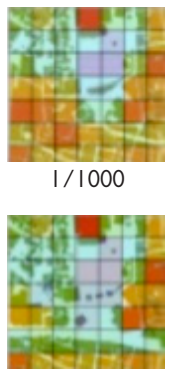

$1 / 1000$

Figure 8. Grids for Varying Scale Levels Superimposed Upon 1946 (Upper) and 2013 (Lower) Vector Data and Unit-Specific G Realizations

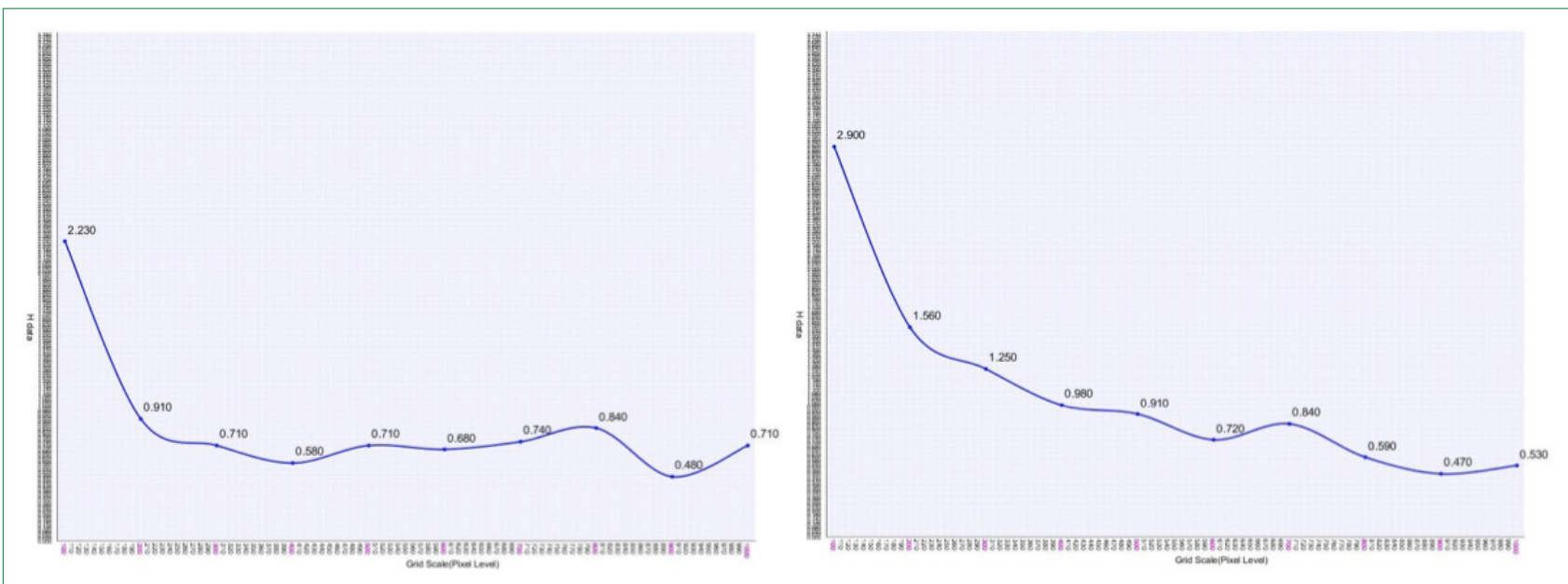

Figure 9. Multi-Scalar analysis and G-IQR (red curve) and H-IQR (blue curve) results for 1946 (left) and 2013 (right) data

Table I. G-IQR and H-IQR values and their quartiles generated for 1946 data

\section{Grid scale Pixel level Total Cell NA Cell G-IQR QI $\quad$ Q3 H-Mean H-Median H-IQR QI $\quad$ Q3 H-Max H-Min}

\begin{tabular}{cccccccccccccc}
\hline 100 & $15 * 15$ & 4761 & 272 & 0.870 & 0.130 & 1.000 & 2.290 & 2.900 & 1.450 & 1.720 & 3.170 & 3.780 & 0.000 \\
200 & $30 * 30$ & 1225 & 136 & 0.610 & 0.300 & 0.910 & 2.580 & 3.010 & 0.780 & 2.400 & 3.180 & 3.560 & 0.000 \\
300 & $45 * 45$ & 529 & 88 & 0.485 & 0.360 & 0.845 & 2.630 & 3.040 & 0.680 & 2.510 & 3.190 & 3.560 & 0.000 \\
400 & $60 * 60$ & 324 & 68 & 0.420 & 0.420 & 0.840 & 2.730 & 3.100 & 0.600 & 2.610 & 3.200 & 3.360 & 0.000 \\
500 & $75 * 75$ & 196 & 52 & 0.375 & 0.435 & 0.810 & 2.670 & 3.050 & 0.710 & 2.470 & 3.190 & 3.370 & 0.000 \\
600 & $90 * 90$ & 144 & 44 & 0.365 & 0.445 & 0.810 & 2.750 & 3.060 & 0.680 & 2.510 & 3.190 & 3.320 & 0.660 \\
700 & $105 * 105$ & 100 & 36 & 0.345 & 0.445 & 0.790 & 2.660 & 2.980 & 0.740 & 2.440 & 3.180 & 3.360 & 1.000 \\
800 & $120 * 120$ & 81 & 32 & 0.355 & 0.445 & 0.800 & 2.650 & 2.940 & 0.840 & 2.310 & 3.150 & 3.340 & 1.330 \\
900 & $135 * 135$ & 64 & 28 & 0.375 & 0.425 & 0.800 & 2.750 & 2.930 & 0.480 & 2.550 & 3.030 & 3.290 & 1.920 \\
1000 & $148 * 148$ & 49 & 24 & 0.380 & 0.400 & 0.780 & 2.600 & 2.670 & 0.700 & 2.340 & 3.040 & 3.210 & 2.040 \\
\hline
\end{tabular}

les as shown in Figure 8. Multiple-grid-scaled analyses, shown in the graphs in below Figure 9, revealed that the change with the entropic state, as seen in the below Tables I and 2, has deteriorated, from 0,77bit to I,02bit entropy level within last sixty years.
As seen in Table I, for 1946 case study layout, the mean of the $\mathrm{H}-\mathrm{IQR}$ values for the pixel levels that have been tested is $0,77 \mathrm{bit}$.

As seen in Table 2, for 2013 case study layout, the mean of the $\mathrm{H}-\mathrm{IQR}$ values for the scales that have been tested is I,02bit. 
Table 2. G-IQR and $H-I Q R$ values and their quartiles generated for 2013 data

\begin{tabular}{cccccccccccccc}
\hline \multicolumn{2}{l}{ Grid scale Pixel level Total Cell NA Cell G-IQR } & QI & Q3 & H-Mean H-Median H-IQR & QI & Q3 & H-Max H-Min \\
\hline 100 & $15 * 15$ & $476 I$ & 272 & 1.000 & 0.000 & 1.000 & 2.040 & 2.650 & 2.390 & 0.760 & 3.150 & 3.720 & 0.000 \\
\hline 200 & $30 * 30$ & 1225 & 136 & 0.765 & 0.115 & 0.880 & 2.320 & 2.770 & 1.470 & 1.700 & 3.170 & 3.740 & 0.000 \\
300 & $45 * 45$ & 529 & 88 & 0.695 & 0.150 & 0.845 & 2.370 & 2.590 & 1.260 & 1.900 & 3.160 & 3.610 & 0.000 \\
400 & $60 * 60$ & 324 & 68 & 0.615 & 0.225 & 0.840 & 2.540 & 2.760 & 0.980 & 2.180 & 3.160 & 3.470 & 0.000 \\
500 & $75 * 75$ & 196 & 52 & 0.560 & 0.240 & 0.800 & 2.440 & 2.670 & 0.900 & 2.080 & 2.980 & 3.410 & 0.000 \\
600 & $90 * 90$ & 144 & 44 & 0.505 & 0.310 & 0.815 & 2.550 & 2.750 & 0.720 & 2.310 & 3.040 & 3.450 & 0.770 \\
700 & $105 * 105$ & 100 & 36 & 0.520 & 0.280 & 0.800 & 2.520 & 2.660 & 0.840 & 2.220 & 3.070 & 3.330 & 1.040 \\
800 & $120 * 120$ & $8 I$ & 32 & 0.500 & 0.270 & 0.770 & 2.510 & 2.690 & 0.590 & 2.370 & 2.960 & 3.250 & 1.330 \\
900 & $135 * 135$ & 64 & 28 & 0.420 & 0.360 & 0.780 & 2.500 & 2.510 & 0.470 & 2.370 & 2.840 & 3.060 & 1.930 \\
1000 & $148 * 148$ & 49 & 24 & 0.390 & 0.360 & 0.750 & 2.490 & 2.650 & 0.530 & 2.260 & 2.790 & 2.900 & 2.000 \\
\hline
\end{tabular}

The changing trend with the quartiles for each grid level indicates that there is a decrease in the $\mathrm{H}-\mathrm{Q} \mathrm{I}$ at smaller grid scales for the 2013 data compared to 1946 data. This is because of relatively dense spatial layout - which prevent extreme jumps between units' G values - of 1946 layout compared to 2013 . G-QI values for 2013 data change notably slower compared to 1946. This is mostly because of the massive destruction and thus the rising amount of empty areas in 2013 built configuration. Analyses made using the same grid scales generated the graphs in Figure 9 above, show the change of entropy, $\mathrm{H}-\mathrm{IQR}$ values, depending on the changing morpho-information translated by the same size of grid units for both time periods. From smaller to larger pixel levels, 2013 spatial configuration generated relatively higher G-IQR and H-IQR values compared to 1946 configuration. In brief, analyses for the selected areas reveals a higher tendency for uncertainty in micro scales but the lower tendency in larger scales. This outcome verifies and points out to the fact that there is always a higher potential of spatial interaction among the references of micro space towards change. As the grid scale gets larger, the number of the grid units decreases and the number of exempted units proportionally increases due to larger unit size. This leads to the remark that entropy assessment is not only spatial layout dependent notion but also the level of investigation.

\section{Visualizing the Multi-Scalar Relationality}

The color-coding way of data-visualization for $\mathrm{G}, \mathrm{P}$, and $\mathrm{H}$ is one of the two significant informative data-visualizations that

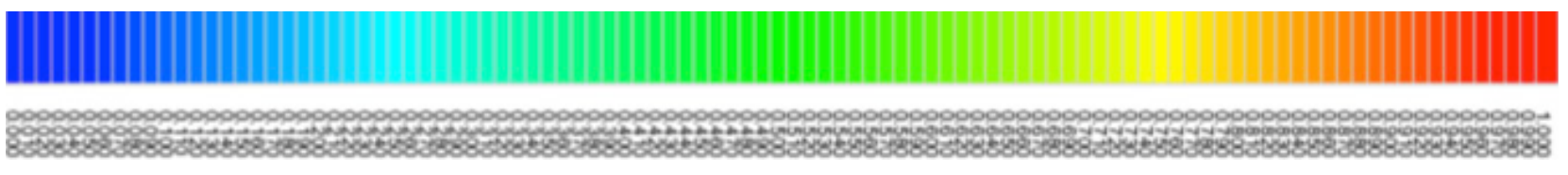

Figure I0. RGB color tones matching I0I G values from 0.00 to 1.00

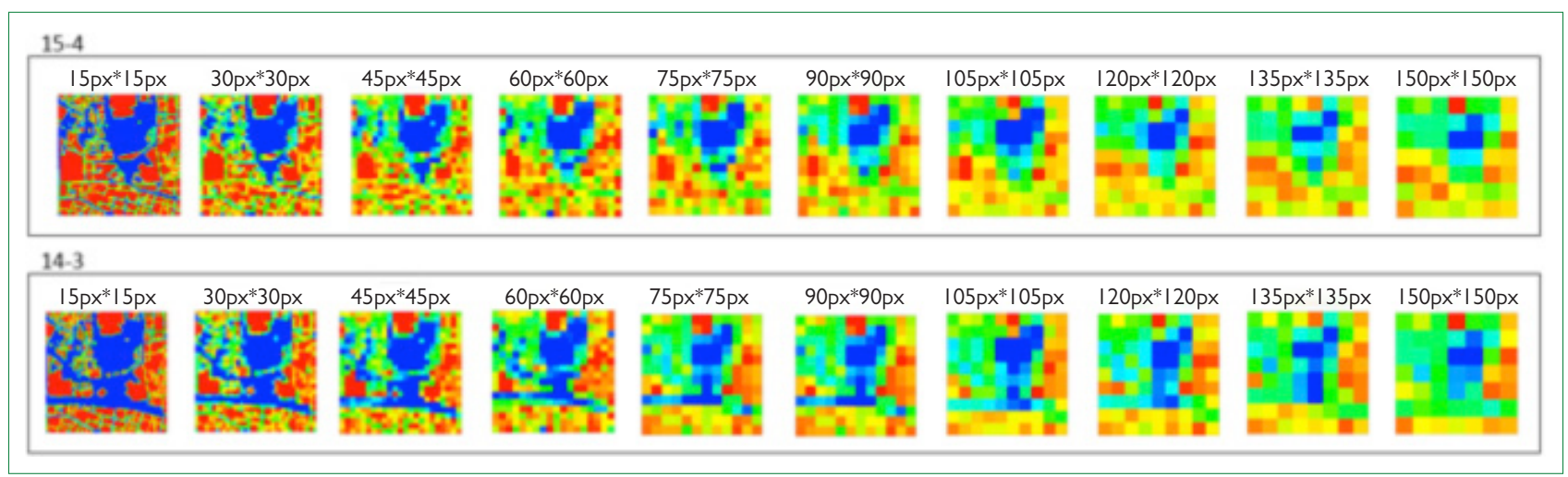

Figure I I. G-CC (G color-coding) visualizations for 1946 (Upper) and 2013 (Lower) morphologic layouts 
has been developed as part of the analysis system.

Each dataset that has been generated through data-mining tool contains unit-specific $G$ values, range from 0,00 to 1,00 , as shown in Figure 10 colour palette. This function assigns a color tone to every single matching unit. In doing so, the area can be visualized depending on the unit-specific built portions through varying size of units. This kind of visualization allows observing the way built entities on a layout make clusters from the units-based morphologic translation point of view as shown in Figure II. Visualized $G$ values allow the analysis tool to show the relevant $P$ and 9-units specific $H$ values on the screen as the user moves the mouse around the units overlaid upon the case study area.

\section{Conclusions}

Alexander (2002-2005, p24I) in "Theory of Wholeness" states that fifteen properties are not independent. This can be taken as an answer to the question of "which property creates a more coherent and deeper wholeness." He leaves an open door for the emergence of wholeness via endless possibilities that the centers may come together to make larger systems. In other words, the relationality of the system parts not only in a specific level but in various levels matter. The way that Alexander (2002-2005, s. 246) associates good functional order with good spatial coherence is confirmed by French philosopher and mathematician Maupertius' (Harris, 2012) concept of "minimum energy consumption \& maximum efficiency" for the systems using the metaphor of a tree. This, once again, reminds that wholeness is not only a narrow idea of physical space but a larger spatial-functional life world. Spatial evolution or change, with an increasing trend, has been studied through diverse map-comparison technics in which both traditional and advanced techniques have been incorporated for various purposes such as location-based detection of temporal/spatial change, comparing different models or scenarios, or for calibrating/validating land use models (Visser \& de Nijs, 2006). The novelty that this method introduces, about morphologic measuring and visualization, is that it measures built environment through the notion of spatial relatedness using the information of gradually larger or smaller spatial units which morphologically and intuitively articulates a relative degree of wholeness. Such wholeness, in addition to being context dependent, is also about the scale level of a gridal investigation since the system continually redefines its entropy through the changing morphologic interplay among the adjacent grid units. The fundamental principles, that the method has been developed upon, also draw the path for the development of the methodologic approach that will also consider the third dimension in the built environment. In other words, the consideration of the third dimension of the buildings in a complex built environment using the multi-scalar data-translation interface of the method will be the major focus for modeling the wholeness of the topview and/or various elevational views. Planning and design in today's world have shifted to a level of making decisions that rely on data-intense and evidence-based methods. The tool, using different goal-directed raw data types, allows modeling various types of relationalities - social, economic and environmental - through the axis of time and space.

This study develops an evidence-based approach for measuring spatial wholeness, e.g. completeness, and implements it on Beyazit Square, one of the major squares that has been densely influenced by the effects of automobile-led urban planning trends in Istanbul (Ayvazoglu, 20I2) in the last sixty years. The results show that the degree of the wholeness of the square significantly decreased within last sixty years. This finding is also being verified in previously reported studies, the spatial assessments (IMM, 20I2), (Protection Board, 20I3) that have been developed by the experts in Metropolitan Municipality of Istanbul and in Istanbul 4th Protection Board for Cultural Assets. Both reports point out the poor and fragmented spatial quality of the square noting the remarkable morphologic change that the square faced within the last sixty years.

Being alive, in biological terms, is a very binary matter. There are only two major degrees, dead or alive, and no other states of existence. In space, there are varying degrees of completeness or incompleteness and this study hypothesizes that it is a measurable concept beyond intuition (Alexander, 2002-2005). Spatial incompleteness as evocative of liminal states is explained as circumstances annoying the user, dissonant matches, uncertain situations, ambiguous formations and undefined regions (Karaali \& Karagol, 20I3). Adapted to spatial analysis, there are varying degrees of completeness or incompleteness in the built environment and this study, using Shannon's information entropy theory, demonstrates that wholeness or completeness as spatial quality is a measurable notion. In brief, the proposed method, as an analytical and evidence-based topologic investigation is a promising approach to shed light on the morphologic possibilities and change scenarios in the built environment.

To conclude; by all means, the question of "city as a matter of wholeness" will not make any common definition for everyone since it is not as purely intuitive as Alexander (20022005) suggests. Even a catalog of the fifteen properties that Alexander structurally defines for his definition of wholeness doesn't sound complete. It becomes misleading when conceiving wholeness as a solely physical property. Either spatial or functional, wholeness, as an urban spatial quality, requires a comprehensive looking at physical, cultural and mental everything what makes a "city". Therefore, questioning the notion 
of wholeness out of two-dimensional spatial data, through referencing Alexander, seems formally correct yet a debatable attempt. This review is the weakest aspect of the proposed method which in contrary also promises a broad perspective in comprehending the mathematical logic of physical space attached to its manifold social and semantic context.

Major urban design theories, such as "Image of the City" (Lynch, 1960), "Townscape" (Cullen, 196I), "Death and Life of Great American Cities" (Jacobs, 196I) and "A City is Not a Tree" (Alexander C., 1965), through varying hypotheses, claims and theories, boil several spatial qualities down to relative configurations - in two or three-dimensional context - of space. All of the above four texts are significant in responding to different aspects of design regarding experiential, artistic, sociopolitical, practical, procedural and structural issues (Marshall, 2012). They are the foundational theories establishing the urban design theory to a significant extent. Marshall (20I2) states that "major urban design theories rest on a foundation of untested and non-validated hypotheses." Proposed method represents an analytical approach to measure whether or not spatial order, property in Alexander's term, in certain relative context promises a degree of wholeness benefitting the concept of entropy borrowed from the information science. In this respect, the proposed method, as an attempt to test a claim, contributes to the scientific accumulation of urban design theory.

Kempf (2009), states "Although we will never fully comprehend the entire complexity of a city in one moment, we can understand the urban construct through the interaction of its parts." This sort of skeptic questioning that analytically incorporates and methodizes "Shannon's Entropy" and Alexander's claims in "Theory of Wholeness" is an opportunity to reconsider several other social, economic and sustainability issues as interacting matters of urbanism in multi-disciplinary studies.

As an answer to the question of "Is the city one thing or two?" Hillier and Vaughan (2007), states that spatial form needs to be understood as a contributing factor in forming the patterns of integration and segregation in cities. Such as demographic, land-uses, land-values and functional changes, using the proposed method we can understand the dynamic between the changing form of the urban space and the various types of related human activity - social, economic, and cultural - nestled in space in several ways.

\section{Acknowledgement}

This study is a part of Harun Ekinoglu's Ph.D. research. He has been granted a research funding by TUBITAK to carry out his Ph.D. research at Columbia University, GSAPP from $2014 / 9$ to 2015/9. The authors also thank to Siying Du and Bora Koç for their contribution to the development of the Analysis Tool 


\section{REFERENCES}

Alexander, C. (1965). A city is not a tree. Architectural forum 122/1 and 122/2, (Part1)58-61 and (Part2)58-62.

Alexander, C., Neis, H., Anninou, A., \& King, I. (1987). A New Theory of Urban Design. New York: Oxford University Press.

Alexander, C. (1963). Notes on the Synthesis of the Form. Cambridge, Massachusetts: Harvard University Press.

Alexander, C. (2002-2005). The Nature of Order: An Essay on the Art of Building and The Nature of the Universe, Book One, the Phenomenon of Life. San Francisco: Berkeley, California: Center for Environmental Structure.

Alexander, C. (1979). The Timeless Way of Building. New York: Oxford University Press.

Ayvazoglu, B. (2012). Üçüncü Tepede Hayat - Beyazıt Meydanínın Derin Tarihi. İstanbul: Kubbealtı Neşriyatı.

Bailey, K. D. (2015, May). Entropy Systems Theory. Retrieved from Encyclopedia of Life Support Systems (EOLSS): http://www.eolss.net/ebooks/ Sample\%20Chapters/C02/E6-46-01-04.pdf

Bohm, D. (1980). Wholeness and implicate order. London: Routledge.

Claramunt, C. (2005). A spatial form of diversity. In A. G. Cohn, \& D. M. Mark, COSIT, LNCS vol. 3693 (pp. 218-231). Heidelberg: Springer.

Cullen, G. (1961). Townscape. London: Architectural Press.

Eyice, S., \& Kuban, D. (1993). Dünden Bugüne İstanbul Ansiklopedisi. İstanbul: Ministry of Culture \& Foundation of History.

Freely, J. (2011). A History of Ottoman Architecture. WIT.

Harris, J. (2012). Fractal Architecture. China.

Hillier, B., \& Vaughan, L. (2007). The city as one thing. Progress in Planning, 67 (3), 205-230.

IMM. (2012). Beyazit Square Urban Design Project Unpublished Report. Istanbul: Department of Urban Design, Istanbul Metropolitan Municipality.

Istanbul 4th Protection Board for Cultural Assets. (2013). Board Evaluation Report (No: 20249679/715). Istanbul: Unpublished Report.

Jacobs, J. (1961). The Death and Life of Great American Cities. New York City: Random House.

Jat, M. K., Garg, P. K., \& Khare, D. (2007). Monitoring and Modelling of Urban Sprawl Using Remote Sensing and GIS Techniques. International Journal of Applied Earth Observation and Geoinformation, 2643. Retrieved from http://www.sciencedirect.com/science/article/pii/ S0303243407000335

Jiang, B. (2017, January 15). Geographic space as a living structure for predicting human activities using big data. Retrieved from ResearchGate: https://www.reserachgate.net/publication/312332540

Jones, T. (2010, November 30). Data visualization with Processing, Part 1: An introduction to the language and environment. Retrieved 2015, from ibm.com: http://www.ibm.com/developerworks/library/os-datavis/osdatavis-pdf.pdf

Karaali, D., \& Karagöl, A. (2013). The imperfection of the incomplete timeless urban space. ITU A-Z Journal of Architecture Vol.10/1, 17-36.

Karlström, A., \& Ceccato, V. (2002). A new information-theoretical measure of global and local association: S. The Review of Regional Research 22, 13-40.

Kempf, P. (2009). You Are the City [graphic]: Observation, Organization, and Transformation of Urban Settings. Baden, Switzerland: Lars Müller Publishers.

Köhler, W. (1947). Gestalt Psychology: An Introduction to New Concepts in Modern Psychology. New York: LIVERIGHT.

Leibovici, G. D. (2009). Defining Spatial Entropy from Multivariate Distributions of Co-occurrences. In K. S. Hornsby, \& e. a. (eds), Spatial Information Theory (pp. 392-404), aber W'rach: Springer-Verlag Berlin Heidelberg.

Li, H., \& Reynolds, J. (1993). A new contagion index to quantify spatial patterns of landscapes. Landscape Ecology 8, 155-162.

Li, Z., \& Huang, P. (2002). Quantitative measures for spatial information of maps. International Journal of Geographic Information Science 16(7), 699-709.

Lynch, K. (1960). Image of the City. Cambridge: The Technology Press \&
Harvard University Press

Maitre, H., Bloch, I., \& Sigelle, M. (1994). Spatial entropy: a tool for controlling contextual classification convergence. Proceedings of IEEE International Conference on Image Processing ICIP vol. 2, 212-216.

Mandelbrot, B. (1977). Fractals: Form, Chance, and Dimension. W. H. Freeman \& Company.

Mandelbrot, B. (1982). The Fractal Geometry of Nature. San Franciso: W. H. Freeman and Company.

Marshall, S. (2012). Science, pseudo-science and urban design. Urban Design International, V17, Issue 4, 257-271.

Mehaffy, M., \& Salingaros, N. A. (2011, October 24). Point of View. Retrieved from metropolismag.com: http://www.metropolismag.com/ Point-of-View/October-2011/The-Wholeness-Generating-Technologyof-Christopher-Alexander/

Microsoft. (2015, December 10). C\# Programming Guide. Retrieved 2016, from Microsoft Developer Network: https://msdn.microsoft.com/enus/library/67ef8sbd.aspx

Müller-Wiener, W. (2002). İstanbul'un Tarihsel Topoğrafyası. İstanbul: Yap1 Kredi Yayınları.

Shannon, C. E. (1948). A Mathematical Theory of Communication. Bell System Technical Journal 27: 3, 379-423.

Shannon, C. E. (2001). A Mathematical Theory of Communication. ACM SIGMOBILE Mobile Computing and Communications Review V.5/1, 3-55.

Tobler, W. (1970). A computer movie simulating urban growth in the Detroit region. Economic Geography, 46(2), 234-240.

Tupin, F., Sigelle, M., \& Maitre, H. (2000). Definition of spatial entropy and its use for texture discrimination. International Conference on Image Processing Vol. 1, (pp. 725-728).

Waguespack, L. (2010). Thriving Systems Theory and Metaphor-Driven Modeling. Springer.

Wang, T. (2016). Information \& Entropy (Comp 595 DM). Retrieved from http://www.csun.edu/ twang/: http://www.csun. edu/ twang/595DM/Slides/Information\%20\&\%20Entropy.pdf

Visser, H., \& de Nijs, T. (2006). The map comparison kit. Environmental Modelling \& Software 21, 346-358. 